\title{
Use of geochemistry in groundwater vulnerability mapping in Denmark
}

\author{
Birgitte Hansen and Lærke Thorling
}

The principal aim of mapping ground-water vulnerability in Denmark is to ensure optimal protection of present and future drinking-water resources. Groundwater vulnerability mapping of areas up to $1000 \mathrm{~km}^{2}$ has been taking place over the past seven years. The scale of mapping has been adjusted to meet the demands for details of regulation of land use requested by Danish legislation. Groundwater vulnerability mapping comprises analyses and integration of geological, geophysical, hydrological and geochemical data. This paper focuses on the geochemical reactions between groundwater and sediment.

Geochemical knowledge may sometimes not be fully and systematically utilised in groundwater vulnerability mapping. This paper presents different geochemical approaches and demonstrates how these can be successfully integrated with geological, geophysical and hydrological data.

\section{Groundwater vulnerability mapping}

The national groundwater mapping project involves approximately $40 \%\left(17,476 \mathrm{~km}^{2}\right)$ of the total Danish land area classified as particularly valuable for groundwater abstraction, termed OSD in Danish. The mapping has been financed by a surcharge per cubic metre on consumed water. By 2007, approximately $17 \%\left(7066 \mathrm{~km}^{2}\right)$ of Denmark had been mapped (S. Midby, personal communication 2008).

Groundwater mapping in Denmark has focused on nitrate vulnerability mapping. The areas classified in 2005 as nitrate vulnerable OSDs, as based on pre-existing knowledge, or available intensive groundwater mapping, are shown in Fig. 1. In 2005, approximately $15 \%$ of Denmark had been delimitated as nitrate vulnerable OSDs according to the definitions given in Danish legislation. The evaluation of nitrate vulnerability follows a series of criteria, and includes geochemistry of groundwater and aquifer, and the protecting capabilities of the overlying aquitards (Miljøstyrelsen 2000).

\section{Geochemical data types}

The method of large-scale groundwater vulnerability mapping differs from that of a process-oriented scientific field investigation, and it relies extensively on pre-existing data due to the high costs of acquiring new data with sufficient spatial density. The pre-existing data are located in the databases at the Geo- logical Survey of Denmark and Greenland (GEUS) and have been collected over the last century. The geochemical data types used are point information from boreholes and consist of (1) groundwater chemistry data, (2) geochemical sediment data, and (3) colour descriptions of soil layers.

The pre-existing geochemical data have been collected for other purposes than groundwater vulnerability mapping, e.g. drinking-water and irrigation wells. Today, some of these wells have been closed because of poor water quality, but the data are still useful. The distribution in space and time of data from abstraction wells is uneven and these data therefore cannot stand alone. Other existing data for vulnerability mapping come from the national groundwater monitoring network (Stockmarr 2005).

Acquisition of new geochemical data in an OSD area requires a detailed and carefully prepared strategy that presupposes a hydrogeological understanding of the area and an

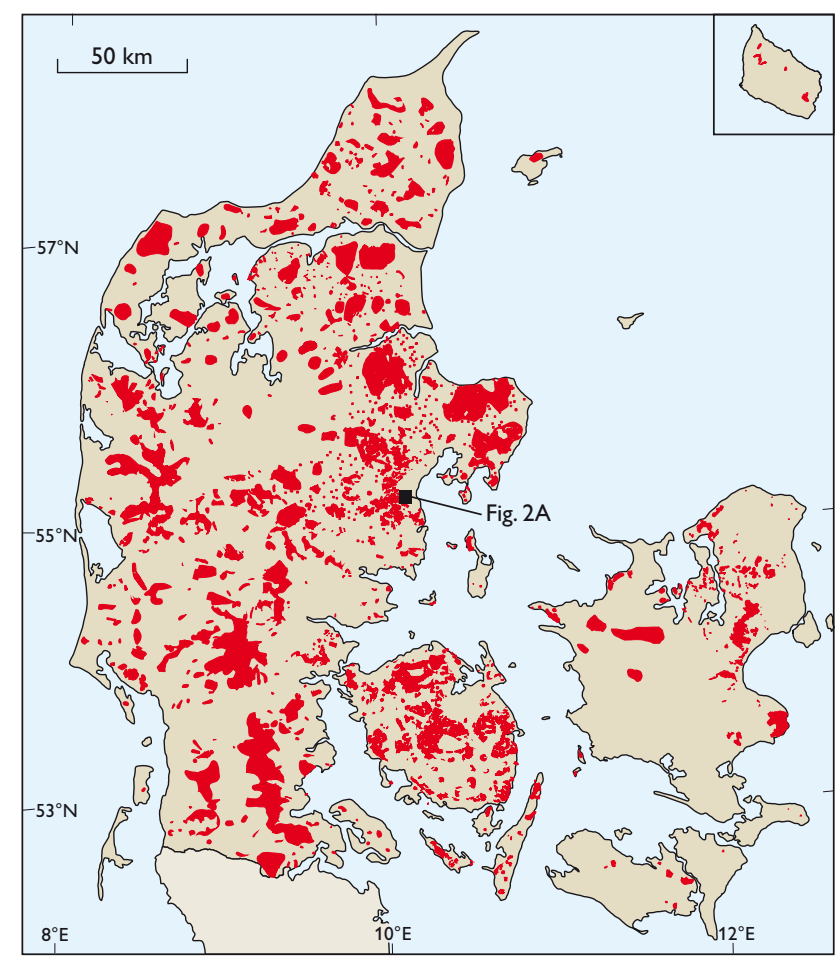

Fig. 1. Groundwater classification map showing abstraction areas that are vulnerable with respect to nitrate pollution of groundwater in Denmark. Modified from the region legislation plans from the county councils (amtsråd) from 2005. 
evaluation of pre-existing geochemical data. New geochemical data are acquired by different techniques. The boreholes may be constructed by using the air-lift technique or conventional auger drilling. The wells are 5-200 m deep with 1-4 screens placed in the aquifer in order to cover the major groundwater quality variations.

The advantage of both air-lift and auger drilling lies in the possibility of obtaining sediment samples for geological interpretation and geochemical analysis of the nitrate reduction capacity. The disadvantage is low resolution of the variations of the groundwater chemistry. The ellog auger drilling method (Sørensen \& Larsen 1999), which allows contemporary groundwater sampling while drilling, provides very important data on the vertical distribution of the groundwater quality (Thomsen et al. 2004). These data provide snapshots of the groundwater chemistry, because the techniques do not allow for permanent screens and soil sample collection.

\section{Geochemical approaches}

\section{Groundwater chemistry}

The interpretation of groundwater quality must take the geochemical processes between water and sediment in the aquifer into account. Each water analysis of redox-sensitive species reflects a certain redox state and can be used to evaluate nitrate vulnerability (Miljøstyrelsen 2000). Special attention must be paid to water samples showing signs of chemical disequilibrium between groundwater and sediment. Such disequilibrium may indicate that nitrate is penetrating into the anaerobic part of the aquifer (Thorling \& Thomsen 2001). The interpretation of the chemical evolution in time series is also an important tool for discovering significant trends towards more subaerobic conditions. The spatial density of groundwater quality data is often poor compared with that of other data types, as the sampling points (screens) are often placed in clusters and only some levels of the aquifers are represented.

\section{Geochemistry of sediments}

The ability of the aquifer sediment to remove leached nitrate mainly depends on its concentration of reducing solid substances such as ferro-ions, pyrite and organic matter. Therefore, another geochemical approach in vulnerability mapping is to estimate the nitrate-reduction capacity based on analyses of the sedimentary content of these substances (e.g. Ernstsen $e t$ al. 2001). Sediment samples should be obtained according to a detailed sampling plan that ensures that they are statistically representative of the examined geological succession, for example in agreement with the theory of sampling (e.g. Petersen $e t$ al. 2005). It is important to obtain samples from both the aer-

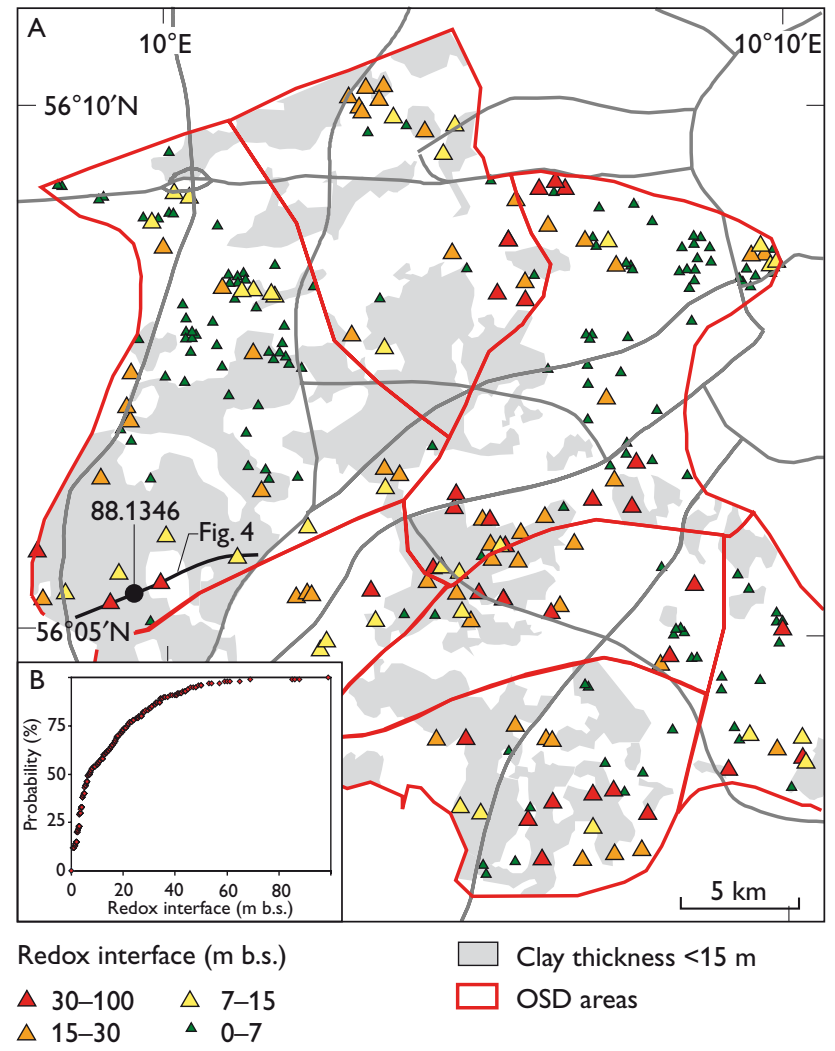

Fig. 2. A: The thickness of clay layers and the position of the redox interface in an area south-west of Århus, Denmark. B: Probability plot of the redoxinterface data shown in $\mathbf{A}$. The location of the area is shown in Fig. 1.

obic and the anaerobic environment. If no detailed sampling plan has been worked out, we recommend collecting samples at one metre intervals in the borehole. The spatial density of the data points for determination of nitrate reduction capacity is often low compared to that obtained by means of other groundwater vulnerability mapping techniques, and this poses a general up-scaling problem (e.g. Hansen et al. 2006).

\section{Interpretation of the redox interface from soil colours}

The transition between aerobic sediment containing nitrate and anaerobic nitrate-free sediment is called the redox interface. Geologically, this interface slowly moves downward in sandy layers by $0.01 \mathrm{~mm}$ to $10 \mathrm{~cm}$ per year as the reductants are oxidised by oxygen and nitrate (Postma et al. 1991). The velocity of the downward movement of the redox interface depends on (1) the reactive content of nitrate-reducing matter; (2) the leaching of nitrate from land use; (3) the water flow and groundwater recharge; and (4) reaction kinetics.

Evaluation of the redox interface based on sedimentary colour descriptions is another feasible approach for nitrate vulnerability mapping. Yellow, red and brown colours indi- 
cate aerobic conditions, while grey colours reflect anaerobic conditions. Colour determination is subjective and is usually done in the field, often by using Munsell soil colour charts. In areas with simple hydrogeological conditions, only one redox interface is found. Complex hydrogeological conditions often result in several redox interfaces in the same borehole, which indicates non-vertical infiltration in a heterogenous geological setting. The spatial density of the redox interface data is high compared with the density of groundwater chemistry data, and approaches the level of lithological data in an area. Thus, the redox-interface data are crucial in groundwater nitrate vulnerability mapping.

\section{Integration of geochemical and geophysical data}

In many areas, the thickness and composition of clay layers overlying aquifers play an important role in protecting groundwater against nitrate and other anthropogenic contaminants (Thomsen et al. 2004). Information about the nitrate vulnerability of an area can be obtained by combining data from geophysical mapping of the total clay content in the upper $30 \mathrm{~m}$ of the subsurface with area-distributed data of the redox interface based on soil colours. The geophysical data are commonly acquired using the pulled array continuous electrical sounding method (Sørensen 1996). Figure 2A shows an example from an approximately $150 \mathrm{~km}^{2}$ OSD area in Jylland, Denmark. Colour descriptions come from about 460 boreholes made in the period 1930-2006. The large variations in the depth of the redox interfaces, even between closely situated data points, are a consequence of the geological heterogeneity in the area.

There is generally good agreement between areas where the redox interface has migrated to great depths $(>7 \mathrm{~m}$ below surface: b.s.) and areas where the thickness of the clay layers is small $(<15 \mathrm{~m})$, presumably due to higher influx of oxidants because of high permeability. The depth of the redox interface in the area varies between the surface and $c .99 \mathrm{~m}$ b.s. In $50 \%$ of the investigated boreholes, the redox interface has migrated more than $7 \mathrm{~m}$ b.s. (the mean value in Fig. 2B). These areas mostly correlate with areas of low groundwater protection due to low clay content.

\section{Integration of geochemical, geological and hydrological data}

\section{A borehole example}

Appropriate mapping of groundwater nitrate vulnerability depends on integration of geochemical, geological, geophysical and hydrological data. Figure 3 shows data from a $150 \mathrm{~m}$ deep borehole with four screens. Data on water chemistry

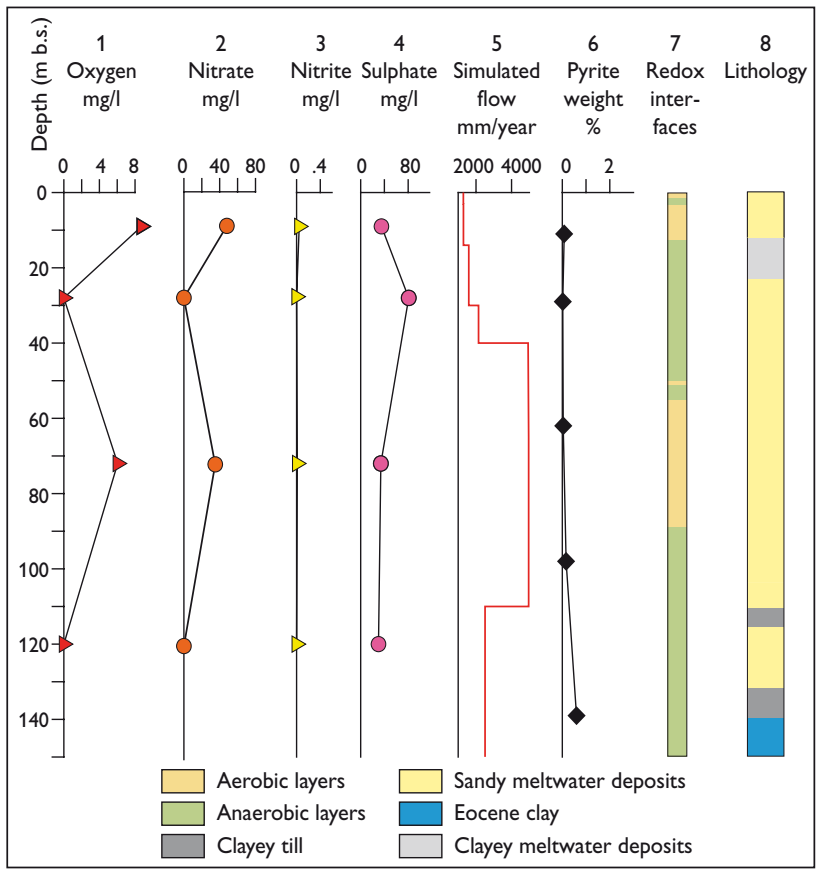

Fig. 3. Chemical, hydrological and geological data for the $150 \mathrm{~m}$ deep well DGU no. 88.1346 located south-west of Århus, Denmark. The location of the well is shown in Fig. 4.

(columns 1-4), groundwater flow simulations based on the MIKE SHE programme (mainly horizontal from $40 \mathrm{~m}$ b.s., column 5), sediment chemistry (column 6), redox interfaces (column 7), and lithology (column 8) are presented. The Quaternary deposits are dominated by sandy sediments with a composite thickness of about $100 \mathrm{~m}$; with meltwater clay in the upper part and till beds in the lower part. The lowest part of the core penetrated impermeable Eocene clay of the Lillebælt Clay Formation. The colours of the sampled succession indicate seven redox interfaces in the borehole. The deepest one is at about $90 \mathrm{~m}$ b. s., and the aerobic/anaerobic zones correlate with the nitrate concentration in the groundwater. Sedimentary pyrite concentration is very low in the anaerobic sandy aquifer $(0.02-0.16 \mathrm{wt} \%)$, which indicates a very low nitrate reduction capacity (up to 40 years per $\mathrm{m}$ ) of the aquifer and a relatively fast-moving redox interface $(c .2 .5 \mathrm{~cm}$ per year). The simulated, mainly horizontal groundwater flow in the primary aquifer in the area of the borehole is very high (up to $4 \mathrm{~m}$ per year). The presence of nitrate and the low nitrate reduction capacity support these hydrological findings.

Lithological analyses of the concentration of different unstable Ca-carbonate minerals in the fine gravel fraction show a high degree of weathering in the sandy meltwater deposits, although the groundwater remains saturated with calcite (Hansen et al. 2006). These data also correlate well with the water chemistry (nitrate concentration), geochemistry of the sediments (low pyrite concentration), and groundwater flow simulations (high groundwater flow). 


\section{A profile example}

Figure 4 shows an example of geological and geochemical conceptual models from an approximately $4 \mathrm{~km}$ long profile through a buried valley in Jylland, Denmark (e.g. Jørgensen \& Sandersen 2008 - this volume). The left borehole (DGU no. 88.1346) on the profile is also shown in Fig. 3. The boreholes and geophysical electrical data (see Fig. 2) show that clay is of limited extent, which makes the aquifer highly vulnerable to nitrate and pesticides. The depth of the redox interface varies significantly along the profile and several redox interfaces can be found in the same borehole indicating a heterogeneous flow regime.

Nitrate, pesticides (Des-Dip-Atrazine) and the pesticide degradation product BAM have penetrated deeply, to about $90 \mathrm{~m}$ b.s. into the aquifer as shown by the yellow areas in Fig. 4B. Vast parts of the aquifer are polluted by nitrate and pesticides. The groundwater chemistry support the understanding of the redox interface and the geological setting. Future extraction of groundwater from the deeper parts of the aquifer could worsen the nitrate and pesticide pollution of the primary aquifer due to increased flow.

\section{Future perspectives}

In order to improve mapping of groundwater nitrate vulnerability there is a general need to develop the sampling and interpretation techniques for sedimentary geochemical analysis. Up-scaling of geochemical data interpretation in groundwater mapping is also a scientific field with high potential. The development of new methods for integrating geological, geophysical, hydrological and geochemical data is also very important. Future focus should be on the development of guidelines for geochemical groundwater mapping and interpretation in a three dimensional perspective. The development and experience from Denmark described here could be very useful for the EU member states working with large-scale mapping under the Water Framework Directive.

\section{References}

Ernstsen, V., Henriksen, H.J. \& von Platen, F. 2001: Principper for beregning af nitratreduktion i jordlagene under rodzonen, $54 \mathrm{pp}$. Arbejdsrapport no. 24. København: Miljøstyrelsen.

Hansen, B., Jordt, B.E., Thomsen, R., Sørensen, J., Kronborg, C. \& Nielsen, O.B. 2006: Gebyrkortlægning i Århus Syd - Geologisk, kemisk og hydrologisk datasammenstilling. Geologisk Nyt 3/06, 18-22.

Jørgensen, F. \& Sandersen, P.B.E. 2008: Mapping of buried tunnel valleys in Denmark: new perspectives for interpretation of the Quaternary succession in Denmark. Geological Survey of Denmark and Greenland Bulletin 15, 33-36.
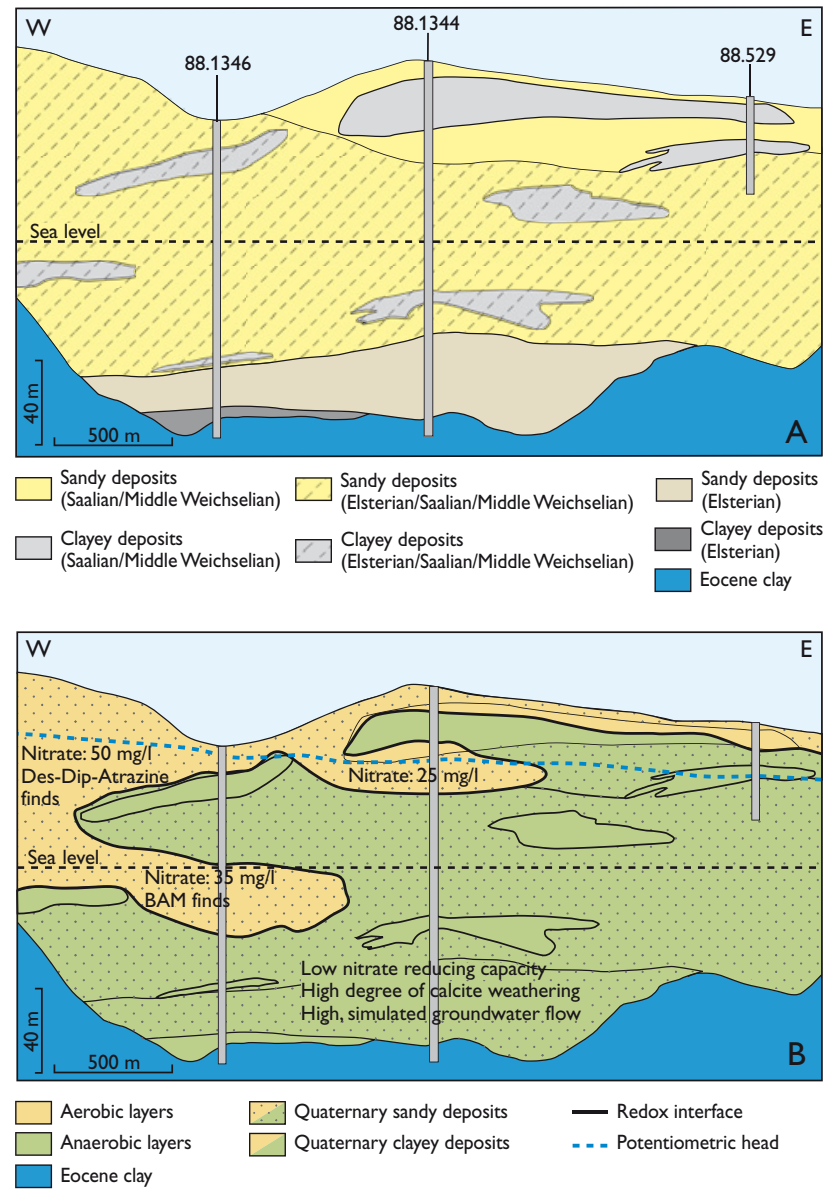

Fig. 4. A buried valley south of Århus, Denmark. A: Geological conceptual profile. B: Geochemical conceptual profile. The boreholes are identified with DGU numbers. The location of the profile is shown in Fig. 2A.

Miljøstyrelsen 2000: Zonering. Detailkortlægning af arealer til beskyttelse af grundvandsressourcen. Vejledning fra Miljøstyrelsen 3, 153 pp. København: Miljøstyrelsen.

Petersen, L., Minkkinen, P. \& Esbensen, K.H. 2005: Representative sampling for reliable data analysis: theory of sampling. Chemometrics and Intelligent Laboratory Systems 77, 262-277.

Postma, D., Boesen, C., Kristiansen, H. \& Larsen, F. 1991: Nitrate reduction in an unconfined sandy aquifer: water chemistry, reduction processes, and geochemical modeling. Water Resources Research 27, 2027-2045.

Sørensen, K. 1996: Pulled array continuous electrical sounding. First Break 14, 85-90.

Sørensen, K.I. \& Larsen, F. 1999: Ellog auger drilling: 3-in-one method for hydrogeological data collection. Ground Water Monitoring \& Remediation 19, 97-101.

Stockmarr, J. 2005: Groundwater quality monitoring in Denmark. Geological Survey of Denmark and Greenland Bulletin 7, 33-36.

Thomsen, R., Søndergaard, V.H. \& Sørensen, K.I. 2004: Hydrogeological mapping as a basis for establishing site-specific groundwater protection zones in Denmark. Hydrogeology Journal 12, 550-562.

Thorling, L. \& Thomsen, R. 2001: Tunø. Status report 1989-1999, 27 pp. Århus: Aarhus County, Environmental Division.

\section{Authors' address}

Geological Survey of Denmark and Greenland, Lyseng Allé 1, DK-8270 Højbjerg, Denmark. E-mail:bgh@geus.dk 